\title{
Analisis Pendapatan Petani Jagung Pulut (Zea mays var. Ceratina) Di Kelurahan Mangkoso Kecamatan Soppeng Riaja Kabupaten Barru
}

\author{
Income Analysis of Pulut Corn (Zea mays var. Ceratina) Farmers in Mangkoso Village, \\ Soppeng Riaja District, Barru Regency \\ Subehan Harun $^{1 *}$, Irmayani ${ }^{1}$, A. Erna Sriwahyuningsih ${ }^{1}$ \\ *Email: Subehanharun12@gmail.com \\ ${ }^{1}$ Program Studi Agribisnis, Fak. Pertanian, Peternakan dan Perikanan, Universitas Muhammadiyah Parepare
}

Diterima: 01 Mei 2021 / Disetujui: 02 Agustus 2021

\begin{abstract}
ABSTRAK
Penelitian ini bertujuan untuk mengetahui pendapatan petani jagung pulut di Kelurahan Mangkoso Kecamatan Soppeng Riaja Kabupaten Barru. Penelitian ini di laksanakan pada bulan Agustus 2020 sampai Oktober 2020, bertempat di Kelurahan Mangkoso Kecamatan Soppeng Riaja Kabupaten Barru. Penentuan responden di lakukan dengan metode total sampling yaitu semua petani yang ada di Kelurahan Mangkoso dengan jumlah sampel 37 petani. Metode analisis yang di gunakan adalah pendapatan dan kelayakan. Hasil penelitian menunjukkan bahwa rata-rata produksi jagung pulut dalam satu kali musim tanam di Kelurahan Mangkoso Kecamatan Soppeng Riaja Kabupaten Barru sebesar 4.480/ tongkol dan rata-rata penerimaan yang diperoleh petani sebesar Rp. 3.499.135/ are, sedangkan total biaya yang dikeluarkan petani rata-rata sebesar Rp. 1.500.623/ are dan pendapatan usahatani jagung pulut di Kelurahan Mangkoso Kecamatan Soppeng Riaja Kabupaten Barru Rp. $1.998 .512 /$ are.
\end{abstract}

Kata Kunci : Usahatani, Jagung Pulut, Pendapatan, Kelayakan

\section{ABSTRACT}

This study aims to determine the income of pulut corn farmers in Mangkoso Village, Soppeng Riaja District, Barru Regency. This research was conducted in August 2020 to October 2020, located in Mangkoso Village, Soppeng Riaja District, Barru Regency. Determination of respondents was done by total sampling method, namely all farmers in Mangkoso Village with a total sample of 37 farmers. The analysis method used is income and eligibility. The results showed that the average production of pulut corn in one planting season in Mangkoso Village, Soppeng Riaja District, Barru Regency was 4,480 / ear and the average income obtained by farmers was Rp. 3,499,135 / acre, while the total cost incurred by farmers is an average of Rp. 1,500 623 / acre and income from pulut corn farming in Mangkoso Village, Soppeng Riaja District, Barru Regency Rp. 1,998,512 / are.

Keywords: Pulut Corn, Farming, Income, Feasibility

(c) (1) This work is licensed under Creative Commons Attribution License 4.0 CC-BY International license

\section{A. PENDAHULUAN}

Kelurahan Mangkoso, Kecamatan Soppeng Riaja, Kabupaten Barru jagung pulut ditanam 2 sampai 3 kali dalam setahun pada bulan Mei/ Juni, pada bulan Juli/ Agustus, dan pada bulan September/ Oktober. Umumnya petani menanam padi di sawah tadah hujan, setelah padi dipanen penduduk memotong jerami kemudian lahan sawah ditanami jagung pulut. Jagung pulut juga ditanam diladang, baik pada musim hujan maupun pergantian antara musim penghujan menuju musim kemarau. 
Tabel 1. Produksi, Luas Panen dan Produktivitas Jagung di Kecamatan Soppeng Riaja Tahun 2015-2018

\begin{tabular}{ccccc}
\hline No & Tahun & Produksi (Ton) & Luas panen $(\mathbf{H a})$ & Rata-Rata Produksi Jagung $(\mathbf{K g} / \mathbf{H a})$ \\
\hline 1 & 2015 & 172,41 & 49,00 & 35,19 \\
2 & 2016 & 56,00 & 12,00 & 46,67 \\
3 & 2017 & 87,62 & 21,00 & 41,72 \\
4 & 2018 & 363,08 & 79,00 & 45,90 \\
5 & 2019 & 326,34 & 68,00 & 47,99 \\
\hline \multicolumn{2}{l}{ Sumber : Badan Pusat Statistik, 2020.}
\end{tabular}

Jagung pulut merupakan salah satu jenis jagung yang memiliki karakter unik. Jagung pulut mempunyai cita rasa yang enak, lebih gurih, lebih pulen dan lembut dari jagung pada umumnya. Rasa gurih pada jagung ini karena kandungan amilopektin yang terkandung dalam jagung pulut sangat tinggi, mencapai $90 \%$ Jagung ini pertama kali ditemukan di Cina pada awal 1900 yang pada saat itu menjadi komodas pangan di daerah Sulawesi Selatan. Jagung pulut dibuat bahan pembuatan bubur di Manado dan Barobbo Sulawesi Selatan.

Hasil perjalanan eksplorasi jagung pulut di Sulawesi Selatan ( Wawo et al. 2012) menunjukkan bahwa jagung pulut sangat potensial untuk dikembangkan dalam menunjang keanekaragaman pangan dan untuk meningkatkan pendapatan petani. Jagung pulut ditanam di beberapa kabupaten diantaranya Maros, Takalar, Jeneponto, Pangkajene, dan Barru. Jagung pulut memiliki potensi ekonomi untuk meningkatkan pendapatan masyarakat lokal, pedagang jagung pulut rebus di Sulsel cukup tinggi, rata-rata mencapai 2000 - 3000 tongkol/ hari/ unit penjualan dengan harga Rp. 1000/ tongkol. Hasil penelitian usahatani jagung pulut (Syuryawati \& Faesal 2009) menunjukkan bahwa keuntungan yang dicapai petani pada panen tongkol muda sebesar Rp. 12.807.500,- per ha dengan $\mathrm{R} / \mathrm{C}$ ratio 4,33. Berdasarkan latar belakang, dapat dirumuskan masalah penelitian sebagai berikut : 1). Berapa rata-rata pendapatan petani jagung pulut di Kelurahan Mangkoso Kecamatan Soppeng Riaja Kabupaten Barru ?dan 2) Apakah usahatani jagung pulut di Kelurahan Mangkoso Kecamatan Soppeng Riaja Kabupaten Barru layak untuk diusahakan.

\section{B. METODE PENELITIAN}

\section{Tempat dan Waktu}

Penelitian ini dilaksanakan selama dua bulan yaitu pada bulan Agustus 2020 sampai Oktober 2020 yang bertempat di Kelurahan Mangkoso Kecamatan Soppeng Riaja Kabupaten Barru. Terpilihnya Kelurahan Mangkoso sebagai 
lokasi penelitian atas dasar pertimbangan sebagian besar masyarakat Kelurahan Mangkoso adalah petani jagung pulut.

\section{Populasi dan Sampel}

Populasi dalam penelitian ini adalah semua petani jagung pulut di Kelurahan Mangkoso yang berjumlah 37. Karena populasi dalam penelitian ini hanya 37 maka populasi yang di masukkan sebagai sampel, dengan rumus Arikunto (2002) apabila jumlah populasi <100 maka jumlah sampel sama dengan jumlah populasi. Jika jumlah populasi >100 maka sampel dapat diambil sebanyak 10-15\%.

\section{Analisi Data}

Menurut (Sugiono, 2015) "Analisis data adalah proses mencari dan menyusun secara sistematis data yang diperoleh dari hasil wawancara,catatan, lapangan, dan dokumentasi, dengan cara mengorganisasikan data ke dalam kategori, menjabarkan ke dalam uni-unit, melakukan sintesa, menyusun kedalam pola, memilih mana yang penting dan yang akan dipelajari dan membuat kesimpulan sehingga mudah dipahami oleh diri sendiri maupun orang lain.

Untuk menganalisi data dalam penelitian ini digunakan analisis deskriftif kuantitatif diperlukan untuk mengetahui keadaan umum usahatani jagung pulut tersebut secara financial seperti pendapatan usahatani dan kelayakan. Analisis data yang digunakan dalam penelitian ini, adalah :

1. Biaya produksi, Menurut Sudarman (2001), total biaya adalah total biaya tetap ditambah dengan total biaya variabel. Total biaya dihitung dengan rumus :

\section{$\mathrm{TC}=\mathrm{TFC}+\mathrm{TVC}$}

Keterangan :

TC $($ total cost $)=$ Total Biaya Produksi $(\mathrm{Rp})$

TFC $($ Total Fixed Cost $)=$ Total Biaya Tetap (Rp)

TFC $($ Total Variabel Cost $)=$ Total Biaya Variabel ( $\mathrm{Rp})$

2. Penerimaan, Soekartawi (2006) menyatakan penerimaan usahatani adalah perkalian antara volume produksi yang diperoleh dengan harga jual dengan rumus :

$$
\mathbf{T R}=\mathbf{Q} \cdot \mathbf{P}
$$

Keterangan : TR $($ Total Revenue $)=$ Penerimaan Usaha $(\mathrm{Rp})$ Q ( Quantity) = Produk jagung pulut yang dihasilkan (Tongkol)

$\mathrm{P}($ Price $) \quad=$ Harga jual produk jagung pulut per unit (Rp/ Tongkol)

3. Pendapatan, sesuai yang dikemukakan Soekartiwi (2002) pendapatan usahatani adalah selisih antara penerimaan dan semua biaya. Untuk mengetahui pendapatan secara sistematis dirumuskan sebagai berikut

$$
\boldsymbol{\pi}=\mathbf{T R}-\mathbf{T C}
$$

Keterangan :

$\boldsymbol{\pi}=$ Pendapatan usahatani jagung pulut $(\mathrm{Rp})$ TR = Penerimaan total usaha jagung pulut (Rp) 
TC = Total biaya produksi usaha jagung pulut (Rp)

4. Untuk menentukan tingkat kelayakan usaha responden dapat ditentukan dengan menggunakan rumus :

$\mathrm{R} / \mathrm{C}$ Ratio $=\frac{T R}{T C}$

Keterangan :

$\mathrm{R} / \mathrm{C}=$ Retum Cost Rasio

$\mathrm{TR}=$ Total Penerimaan (Total Revenue)

$\mathrm{TC}=$ Total Biaya (Total Cost)

\section{HASIL DAN PEMBAHASAN}

1. Luas Lahan.

Usman dan Julianti (2018) menyatakan luas lahan yaitu besarnya luasan yang dikelola dalam berusahatani untuk menghasilkan produksi. Semakin besar lahan yang dipakai tentunya akan mendapatkan hasil semakin meningkat. Usahatani di ukuran kecil tidak mendapatlkan untung untuk mencukupi kebutuhan petani dan keluarganya. Kebalikannya jika ukuran suatu lahan meningkat, maka kecenderungan dapat memperoleh hasil yang semakin tinggi.

Luas lahan berpengaruh terhadap tingkat pendapatan usahatani jagung, luas lahan yang digarap oleh responden petani jagung pulut bervariasi di Kelurahan Mangkoso Kecamatan Soppeng Riaja Kabupaten Barru. Luas lahan rata-rata yang digarap oleh responden petani jagung sebesar 0,19 Ha.

\section{Penggunaan Benih.}

Benih menentukan keunggulan dari suatu komoditas. Benih yang unggul biasanya tahan terhadap penyakit, hasil komoditasnya berkualitas tinggi dibandingkan dengan komoditas lain sehingga harganya dapat bersaing dipasar (Rahim dan Hastuti, 2008).

Benih merupakan salah satu faktor yang mempengaruhi keberhasilan usahatani. Benih yang unggul, bermutu, tahan terhadap serangan hama dan penyakit merupakan syarat mutlak yang harus dipenuhi dalam pemilihan dan penggunaan benih dalam usahatani. Ratarata responden petani jagung pulut menggunakan benih sebanyak 5,27/ liter dengan harga benih Rp. 15.000/ liter dengan rata-rata biaya yang dikeluarkan petani dalam penggunaan benih sebesar Rp. 79.054/ liter.

\section{Penggunaan Pupuk.}

Penggunaan pupuk dalam kondisi lahan yang kurang air, disamping kurang efektif, juga memberikan akibat buruk bagi pertumbuhan tanaman sehingga tanaman tidak akan tumbuh baik (Gultom, 1998).

Pupuk adalah salah satu faktor produksi yang dapat meningkatkan hasil produksi tanaman apabila penggunaan pupuk dengan dosis yang sesuai 
kebutuhan tanaman. Penggunaan pupuk tepat serta berbagai macam pilihan komposisi pupuk dengan zat yang dibutuhkan tanah. Berdasarkan hasil penelitian, responden petani jagung pulut di Kelurahan Mangkoso menggunakan jenis pupuk Urea dan Phonska. Rata-rata responden petani jagung pulut menggunakan pupuk Urea sebanyak $36,08 \mathrm{~kg} /$ 0,19 Ha dan Phonska sebanyak $36,08 \mathrm{~kg} /$ 0,19 Ha dengan rata-rata biaya yang dikeluarkan petani dalam penggunaan pupuk Urea sebesar Rp. 68.554/ 0,19 Ha dan Phonska sebesar Rp. 86.594/ 0,19 Ha.

\section{Penggunaan Tenaga Kerja.}

Tenaga kerja merupakan factor produksi yang perlu diperhitungkan dalam proses produksi dalam jumlah yang cukup, bukan saja dilihat dari tersedianya tenaga kerja tetapi kualitas dan macam tenaga kerja juga perlu diperhatikan. Jumlah tenaga kerja masih banyak dikaitkan dengan kualitas tenaga kerja, jenis kelamin, musim dan upah tenaga kerja. Bila kualitas tenaga kerja tidak diperhatikan maka akan terjadi kemacetan proses produksi (Soekartawi, 2002).

Penggunaan tenaga kerja yang efektif dan memiliki keterampilan serta kemampuan yang memadai merupakan faktor yang sangat penting dalam mencapai keberhasilan. Total biaya ratarata untuk tenaga kerja yang digunakan sebesar Rp. 170.810/ 0,19 Ha.

\section{Biaya Variabel.}

Menurut Boediono (2010) biaya variabel merupakan biaya yang berubah bedasarkan besar kecilnya output produksi yang dihasilkan. Selain itu, biaya variabel merupakan biaya yang mengalami perubahan karena dipengaruhi oleh perubahan volume produksi. Adapun yang termasuk dalam biaya variabel adalah biaya angkut, upah, biaya untuk bahan mentah dan sebagainya.

Biaya variabel ialah biaya yang berubah-ubah jumlahnya dan dipengaruhi banyak atau sedikitnya jumlah produksi yang dihasilkan petani jagung pulut di Kelurahan Mangkoso Kecamatan Soppeng Riaja Kabupaten Barru. Total rata-rata biaya variabel petani jagung pulut adalah Rp. 896.903/ 0,19 Ha.

\section{Biaya Tetap.}

Menurut Shinta (2011) biaya tetap (Fixed Cost) adalah besarnya biaya yang dikeluarkan dalam menjalankan suatu usaha tanpa dipengaruhi oleh tingkat output yang dihasilkan. Selain itu, biaya tetap merupakan biaya yang dikeluarkan akibat penggunaan sumberdaya tetap dalam suatu kegiatan usaha atau proses produksi dan jumlahnya tetap walaupun 
output yang dihasilkan mengalami perubahan. Adapun contoh biaya tetap seperti : penyusutan alat pertanian, biaya sewa, biaya pajak, iuran irigasi dan biaya tetap lainnya.

Biaya tetap adalah biaya yang relative tetap jumlahnya dan harus dikeluarkan petani jagung pulut di Kelurahan Mangkoso Kecamatan Soppeng Riaja Kabupaten Barru, walau produksi yang diperoleh banyak atau sedikit, dengan kata lain biaya tetap tidak di pengaruhi dengan besar kecilnya produksi yang dihasilkan. Total rata-rata biaya tetap yang dikeluarkan petani jagung pulut adalah Rp. 603.720/ 0,19 Ha.

\section{Biaya Total.}

Biaya total merupakan biaya keseluruhan yang dikeluarkan petani dalam kegiatan usahataninya, meliputi biaya tetap dan biaya variabel. Menurut Maulidah (2012), biaya total merupakan biaya keseluruhan dari penjumlahan biaya tetap dan biaya variabel dalam produksi jangka pendek.

Biaya total yang dikeluarkan secara keseluruhan petani jagung pulut di Kelurahan Mangkoso Kecamatan Soppeng Riaja Kabupaten Barru dengan biaya variabel Rp.896.903 sedangkan untuk biaya tetap Rp.603.720 dan total biaya yang dikeluarkan sebesar Rp.1.500.623.

\section{Penerimaan Usahatani.}

Soekartawi (2006) menyatakan penerimaan usaha tani adalah perkalian antara volume produksi yang diperoleh dengan harga jual. Harga jual adalah harga transaksi antara produsen dan pembeli untuk setiap komoditas. Satuan yang digunakan seperti satuan yang lazim digunakan antara penjual/ pembeli secara partai besar, misalnya: kilogram (kg), kuintal (kw),ton,ikat, dan sebagainya. Penerimaan ditentukan oleh besar kecilnya produksi yang dihasilkan, rata-rata penerimaan petani jagung pulut sebesar Rp.3.499.135/0,19 Ha.

\section{Pendapatan Usahatani.}

Menurut Soekartawi (2002), pendapatan adalah perkalian antara produksi yang diperoleh dengan harga jual dan biasanya produksi berhubungan negatif dengan harga, artinya harga akan turun ketika produksi berlebihan.

Pendapatan merupakan selisih antara penerimaan dengan total biaya yang dikeluarkan selama satu kali musim tanam. Pendapatan adalah pemasukan bagi petani jagung untuk memenuhi kebutuhan keluarganya. Analisis pendapatan usahatani berfungsi untuk mengukur apakah kegiatan usahatani 
menguntungkan atau merugikan bagi petani. Oleh sebab itu, ukuran yamg digunakan untuk menetapkan besarnya pendapatan yang diterima oleh petani adalah selisih antara penerimaan dengan jumlah biaya yang dikeluarkan. Rata-rata produksi yang dihasilkan petani jagung pulut sebesar 4.480 Tongkol/ 0,19 Ha dengan harga rata-rata Rp. 775/ 0,19 Ha, sehingga total penerimaan petani sebesar Rp. 3.499.135 / 0,19 Ha. Total rata-rata biaya yang dikeluarkan petani jagung pulut adalah Rp. 1.500.623/ 0,19 Ha. Besarnya pendapatan yang diperoleh petani jagung pulut di Kelurahan Mangkoso Kecamatan Soppeng Riaja Kabupaten Barru sebesar Rp. 1.998.512/ 0,19 Ha.

\section{Kelayakan.}

Kelayakan merupakan penilaian yang menyeluruh untuk menilai keberhasilan suatu proyek. Dan studi kelayakan proyek mempunyai tujuan untuk menghindari keterlanjuran penanaman modal yang terlalu besar untuk kegiatan yang ternyata tidak menguntungkan. Studi kelayakan atau bisnis merupakan suatu kegiatan mengevaluasi, menganalisis, dan menilai layak atau tidaknya suatu proyek bisnis dijalankan (Jumingan, 2009).
Kelayakan usahatani jagung pulut yang dilakukan oleh petani di Kelurahan Mangkoso Kecamatan Soppeng Riaja Kabupaten Barru dengan menggunkan rumus R/C Ratio Nilai R/C Ratio yang diperoleh sebesar Rp. 2,33 berdasarkan kreteria R/C Ratio >1, maka usaha tersebut layak unruk dikembangkan atau diusahakan, jadi setiap pengeluaran $\mathrm{Rp}$. 1,- akan diperoleh penerimaan sebesar 2,33,- dengan melihat jumlah usahatani yang diperoleh tersebut maka secara ekonomis layak untuk dikembangkan.

\section{KESIMPULAN DAN SARAN}

Hasil penelitian dan pembahasannya dapat diambil kesimpulan bahwa rata-rata pendapatan petani jagung pulut di Kelurahan Mangkoso Kecamatan Soppeng Riaja kabupaten barru dalam satu kali panen selama 2 bulan sebesar Rp. 1.998.512, dan usahatani jagung pulut di Kelurahan Mangkoso Kecamatan Soppeng Riaja Kabupaten Barru layak untuk diusahakan.

\section{DAFTAR PUSTAKA}

Arikunto, S. 2002. Metodologi Suatu Pendekatan Proposal. Jakarta: PT. Rineka Cipta.

Boediono. 2010. Seri Sinopsis Pengantar Ekonomi No. 1 Ekonomi Mikro. Edisi Kedua. Yogyakarta : BPFE.

Badan Pusat Statistik Kabupaten Barru. 2020. Kecamatan Soppeng Riaja Dalam Angka. Badan Pusat Statistik Kabupaten Barru. 
Gultom, 1998. Pengaruh Irigasi terhadap Kinerja Usahatani Padi Sawah dan Distribusi Pendapatan Diantara Faktor-faktor Produksi di Kabupaten Simalungun. Skripsi Fakultas Pertanian Universitas Sumatera Utara, Medan.

Jumingan. 2009. Studi Kelayakan Bisnis. Cetakan Pertama. Jakarta: Bumi Aksara.

Maulidah, S. 2012. Pengantar Manajemen Agribisnis. Malang: UB Press.

Rahim A. dan DRD. Hastuti., 2008. Pengantar Ekonomi dan Pertanian. Penebar Swadaya. Jakarta.

Sudarman. 2001. Teori ekonomi mikro I. Pusat Penerbitan Universitas Terbuka, Jakarta.

Sugiyono. (2015). Metode Penelitian. Bandung: Alfabeta.

Soekartawi, 2002. Analisis Usahatani. Universitas Indonesia Press. Jakarta. Soekartawi,. 2006. Analisis Usahatani. Jakarta. Universitas Indonesia.

Shinta, A. 2011. Ilmu Usahatani. Malang: UB Press.

Usman, U. \& Julianti 2018. Pengaruh Luas Lahan, Pupuk, dan Jumlah Tenaga Kerja Terhadap Produksi Padi Gampong Matang Baloi, Jurnal Ekonomi Pertanian Unimal, 1 (1), 31-39.

Wawo AH,. N. Hidayati \& M. Rahmansyah. 2012. Akses jagung pulut untuk kegiatan penelitian fisiologi dalam menunjang ketahanan pangan nasional. Laporan perjalanan ke Wilayah Sulawesi Selatan 16-20 April 2012. Pusat Penelitian Biologi-LIPI. 